Frequency of the CCR5- $\Delta 32$ Mutation in the Atlantic Island Populations of Madeira, the Azores, Cabo Verde, and São Tomé e Príncipe

Author(s): TAMIRA FREITAS, ANTÓNIO BREHM and ANA TERESA FERNANDES

Source: Human Biology, Vol. 78, No. 6 (December 2006), pp. 697-703

Published by: Wayne State University Press

Stable URL: http://www.jstor.org/stable/41466448

Accessed: 21/06/2014 01:28

Your use of the JSTOR archive indicates your acceptance of the Terms \& Conditions of Use, available at http://www.jstor.org/page/info/about/policies/terms.jsp

JSTOR is a not-for-profit service that helps scholars, researchers, and students discover, use, and build upon a wide range of content in a trusted digital archive. We use information technology and tools to increase productivity and facilitate new forms of scholarship. For more information about JSTOR, please contact support@jstor.org. 


\title{
Frequency of the CCR5-432 Mutation in the Atlantic Island Populations of Madeira, the Azores, Cabo Verde, and São Tomé e Príncipe
}

\author{
TAMIRA FREITAS, ${ }^{1}$ ANTÓNIO BREHM, ${ }^{1}$ AND ANA TERESA FERNANDES ${ }^{1}$
}

\begin{abstract}
There is evidence that the CCR5- $\triangle 32$ mutation confers protection against HIV-1 infection to homozygous individuals. It is believed that this mutation spread through Europe with the Vikings and that it has been subjected to positive selection, leading to a high frequency in Europe $(\approx 10 \%)$. We carried out the present study to determine the 32-bp deletion allele and genotype frequencies of the CCR5 gene (CCR5- $\triangle 32)$ in the Atlantic island populations of Madeira, the Azores, Cabo Verde, and São Tomé e Príncipe. These Atlantic archipelagos were all colonized by the Portuguese in the 15th and 16th centuries, but the latter two received most of their settlers from the West African coast. The frequency of the CCR5- $\Delta 32$ mutation varies between $0 \%$ in São Tomé e Príncipe and $16.5 \%$ in the Azores. The Azores Islands have one of the highest frequencies of homozygotes found in Europe $(4.8 \%)$. There are significant differences $(P<0.05)$ between some of these populations, for example, between São Tomé e Príncipe and Cabo Verde, and even within populations (e.g., Portugal, Madeira, and the Azores).
\end{abstract}

The CCR5- $\triangle 32$ mutation consists of a 32-nucleotide deletion in the CCR5 gene located on chromosome 3p21 (Dean et al. 1996). This gene encodes a protein that serves as an entry port for HIV-1, and this mutation causes a truncation in that protein. Individuals who are homozygous for this mutation are highly resistant to HIV-1 infection (Samson et al. 1996; Dean et al. 1996; Libert et al. 1998), whereas heterozygotes have a slower rate of progression to disease (Grimaldi et al. 2002; Samson et al. 1996; Dean et al. 1996). The CCR5- 432 mutation also seems to confer protection against several diseases, namely, arterial occlusive disease (Ghilardi et al. 2004), rheumatoid arthritis (Pokorny et al. 2005), breast cancer (Degerli et al. 2005), and hepatitis C virus (Wald et al. 2004).

The CCR5- 432 mutation seems to have had its origin in northern Europe, but there is no agreement about its age, which varies from about 700 years ago (with a range of 275-1,875 years) (Stephens et al. 1998) to 5,075 years ago (with

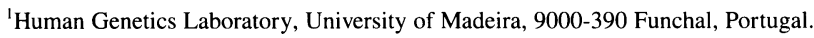

Human Biology, December 2006, v. 78, no. 6, pp. 697-703.

Copyright (C) 2006 Wayne State University Press, Detroit, Michigan 48201-1309

KEY WORDS: CCR5 POLYMORPHISM, ATLANTIC ISLANDS, MADEIRA, AZORES ISLANDS, CABO VERDE, SÃO TOMÉ E PRÍNCIPE, HIV INFECTION. 
a range of 3,150 to 7,800 years) (Sabeti et al. 2005). Lucotte (2001) put forward the hypothesis of a Viking origin for the mutation, suggesting that the mutation already existed in Scandinavia before the Vikings dispersed 1,000-1,200 years ago. A study in Europe shows a high frequency of the CCR5- 432 mutation in areas usually associated with Viking culture, namely, Iceland (14.7\%) and Sweden (14.2\%) (Lucotte 2001), with decreasing frequencies running toward southern Europe (Libert et al. 1998). A study of sub-Saharan Africans shows a very low frequency $(0.16 \%)$ of the mutation for this region (Lucotte 1997), and for North Africa the values are lower $(\approx 1.5 \%)$ than those in Southern Europe (Lucotte 2001), suggesting a European influence in North Africa.

In Europe the gene frequency of the CCR5- $\Delta 32$ mutation is about $10 \%$, resulting in a heterozygous frequency of $18 \%$ and a homozygous frequency of $1 \%$ (Martinson et al. 1997). The mutation's relatively high frequency in Europe has been explained by positive selection of this mutation in those affected by bubonic plague (Stephens et al. 1998), but Galvani and Slatkin (2003) demonstrated that smallpox is a better candidate for positive selection for the CCR5$\Delta 32$ mutation, thus explaining the cline prevailing today in Europe. HIV and poxvirus (responsible for smallpox) enter leukocytes by using chemokine receptors (Lalani et al. 1999), and it is biologically reasonable that the obliteration of the CCR5 chemokine receptor could confer resistance to both HIV and smallpox. Nevertheless, clinical characterizations of HIV and the plague-causing bacillus Yersinia pestis are quite distinct, and Elvin et al. (2004) and Mecsas et al. (2004) showed that deficiency in the chemokine receptor CCR5 in humans is unlikely to protect against plague.

In the present study we tested samples from the Atlantic islands of Madeira, the Azores, Cabo Verde (Cape Verde), and São Tomé e Príncipe, which were all settled by the Portuguese in the 15th and 16th centuries. In particular, Cabo Verde and São Tomé e Príncipe were settled with sub-Saharan slaves brought from the African coast of Guinea and the Gulf of Guinea, respectively, constituting the majority of its population (>90\%; Russell-Wood 1998). We subdivided the population of Cabo Verde into two groups (Cabo Verde North and Cabo Verde South) because recent studies have shown that there are significant differences in the gene pools of these two groups (Brehm et al. 2002; Spínola et al. 2002; Fernandes et al. 2003; Gonçalves et al. 2003). The aim of this study was to observe the frequency of the CCR5- $\Delta 32$ mutation in the Atlantic islands of Madeira, the Azores, Cabo Verde, and São Tomé e Príncipe and to compare the results with frequencies from Portugal (Western Europe) and Guinea-Bissau (West African coast).

\section{Material and Methods}

Blood samples were obtained with informed consent from unrelated individuals originating from the archipelagos of Madeira $(n=119)$, the Azores 
$(n=124)$, Cabo Verde South $(n=127)$, Cabo Verde North $(n=97)$, and São Tomé e Príncipe $(n=100)$. Two populations were further analyzed for comparisons: one from mainland Portugal, further divided into three subregions (south, $n=106$; north, $n=92$; central, $n=91$ ); and a sub-Saharan population from Guinea-Bissau $(n=50)$, located on the West African coast.

DNA extraction was done using conventional phenol-chloroform extraction methods. The CCR5- $\triangle 32$ gene fragment was amplified according to the method of Martinson et al. (1997), and DNA fragments were visualized with silver staining. We assessed Hardy-Weinberg equilibrium of samples and basic genetic parameters such as genotype and allele frequencies for each population using the software program GenePop (Raymond and Rousset 1995). Frequency differences were calculated according to Fisher's exact test using Arlequin (Schneider et al. 1997). Probability values of $P<0.05$ were considered statistically significant.

\section{Results}

All populations are in Hardy-Weinberg equilibrium except the southern Portugal population. This population presented a high frequency of homozygotes for the CCR 5- $\Delta 32$ mutation, but the number of heterozygotes was lower than expected, causing the disequilibrium. Other differences in the genotype frequencies for the CCR 5- $\triangle 32$ mutation among the populations are listed in Table 1. The allele frequency of the CCR5- $\Delta 32$ mutation varies between $0 \%$ in São Tomé e Príncipe and $16.5 \%$ in the Azores (Figure 1).

Interestingly, although expected, the population of Cabo Verde had a relatively high frequency for the mutant allele. In comparison, Guinea-Bissau, the most probable place of origin of slaves brought to Cabo Verde, lacks the CCR5$\Delta 32$ mutation completely. This clearly shows that the CCR5- $\Delta 32$ mutation from Cabo Verde was introduced through admixture by male Caucasian settlers from Europe. In central Portugal the frequency of the mutation is also lower than expected. As verified in a previous study (Fernandes and Brehm 2002), central and northern Portugal show significant genetic differences $(P<0.05)$. The Azores and Madeira also show significant differences with central Portugal. In the present study we did not find significant differences within the Cabo Verde archipelago nor between Cabo Verde and central and southern Portugal. The present study revealed significant differences between the Cabo Verde and São Tomé e Príncipe archipelagos. This is perhaps not surprising because the admixture among Caucasian settlers and sub-Saharan slaves was more pronounced in Cabo Verde than in São Tomé e Príncipe, giving rise to a typical Creole population (Brehm et al. 2002; Spínola et al. 2002; Fernandes et al. 2003; Gonçalves et al. 2003; Trovoada et al. 2004). 
700 / FREITAS ET AL.

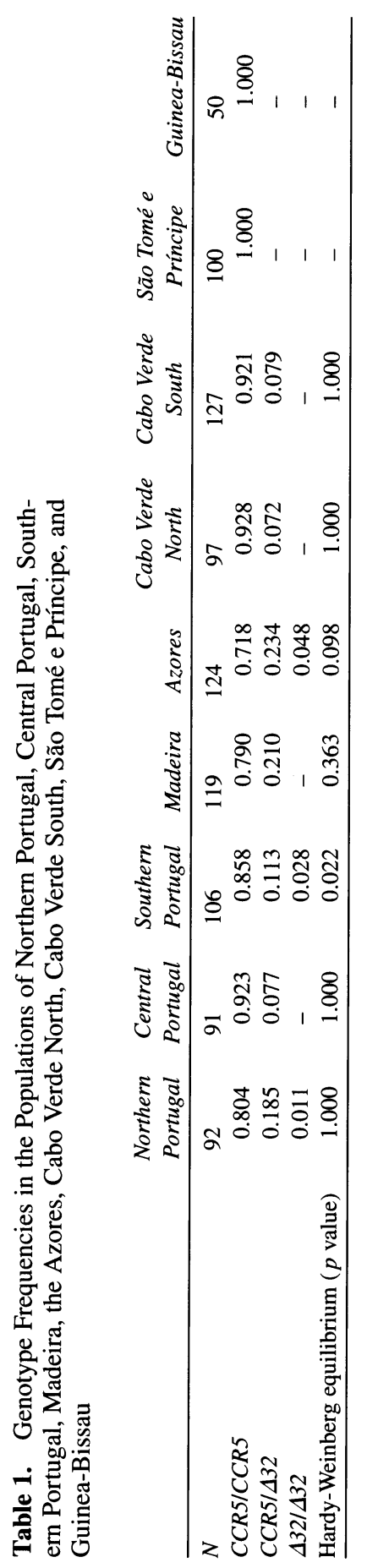




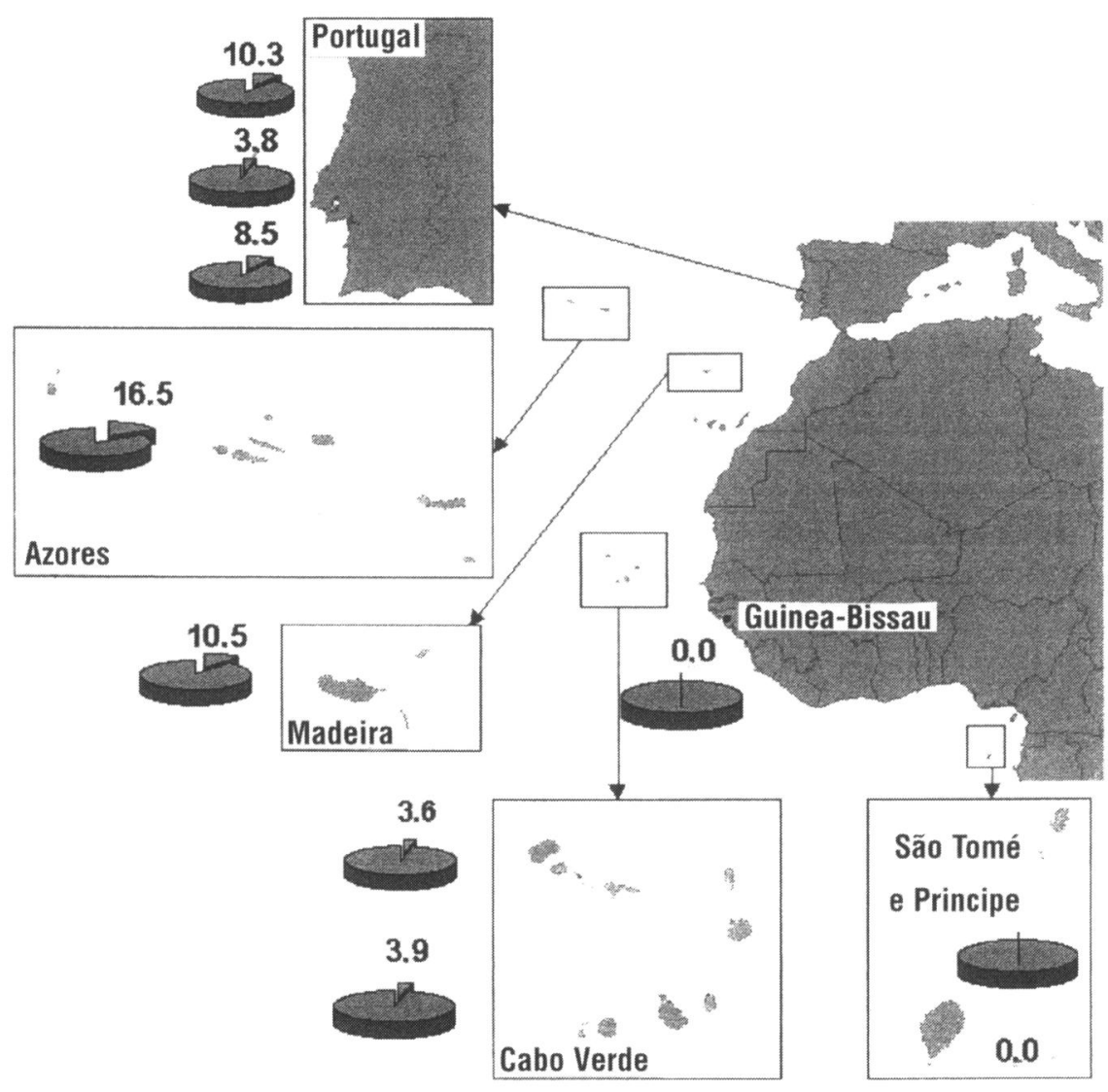

Figure 1. Allele frequencies of the CCR5- $\Delta 32$ mutation from the Atlantic islands of Madeira, the Azores, Cabo Verde (subdivided into north and south groups), and São Tomé e Príncipe plus mainland Portugal (north, central, and south) and Guinea-Bissau.

\section{Discussion}

It seems clear that the frequency of the CCR5- $\Delta 32$ mutation in the population from the Azores Islands is most probably the result of a strong founder effect. The structure of the Azorean population suggests that the founder effect and genetic drift were due to a great influence from northern European populations, a notion that is strengthened by studies of Y-chromosome (Montiel et al. 2005), mtDNA (Santos et al. 2003), and HLA (Spínola et al. 2005) markers. Positive selection must also have occurred, and history describes a smallpox epidemic in 1844-1845 that was devastating in the islands (Amaral 1960).

The population from southern Portugal is in Hardy-Weinberg disequilibrium, although Fernandes and Brehm (2002), in a study performed with exactly 


\section{2 / FREITAS ET AL.}

the same samples but using neutral autosomal STR markers, found the contrary. This is further evidence that positive selection is acting, probably as a result of the entry of smallpox carried by North African populations (Amaral 1960; Hopkins 2002) that settled in the region on several occasions. Unlike other studies (Brehm et al. 2002; Spínola et al. 2002; Fernandes et al. 2003), we found no significant differences between Cabo Verde South and Cabo Verde North. This result can be explained by the fact that the CCR5- $\triangle 32$ mutation was carried mainly by Caucasian male settlers from Europe and there is a large Caucasian influence in both groups of islands: $25 \%$ in the southern group and $42 \%$ in the northern group, according to Gonçalves et al. (2003). Although the explanation for a relative high frequency of the CCR5- $\Delta 32$ mutation in Cabo Verde lies primarily in the strong influence of Caucasians, a second reason could be the occurrence of positive selection for the mutation. Cabo Verde was an important slave-trading center, with slaves coming mainly from Guinea. History reports the introduction of smallpox in Brazil by African slaves in 1555 (Hopkins 2002), and the population of Cabo Verde must have been exposed to the virus at this stage of early colonization.

The Azores and southern Portugal populations have a higher frequency of homozygotes $(4.8 \%$ and $2.8 \%$, respectively) than other European populations (1\%) (Martinson et al. 1997). Because these homozygous individuals seem to be resistant to AIDS, this is a good perspective on these regions in Portugal. The high percentage of the CCR5- $\Delta 32$ mutation in Cabo Verde (compared to other African populations) should always be taken into consideration when studying epidemiological models of the spread of AIDS in Cabo Verde.

Received 28 October 2005; revision received 2 October 2006.

\section{Literature Cited}

Amaral, C. 1960. História da Varíola. Med. Contemp. 78:537-571.

Brehm, A., L. Pereira, H. J. Bandelt et al. 2002. Mitochondrial portrait of the Cabo Verde archipelago: The Senegambian outpost of Atlantic slave trade. Ann. Hum. Genet. 66:49-60.

Dean, M., M. Carrington, C. Winkler et al. 1996. Genetic restriction of HIV-1 infection and progression to AIDS by a deletion allele of the CKR5 structural gene: Hemophilia Growth and Development Study, Multicenter AIDS Cohort Study, Multicenter Hemophilia Cohort Study, San Francisco City Cohort, ALIVE Study. Science 273(5290):1856-1862.

Degerli, N., Y. Emire, and F. Bardakci. 2005. The $\Delta 32$ allele distribution of the CCR5 gene and its relationship with certain cancers in a Turkish population. Clin. Biochem. 38:248-252.

Elvin, S. J., E. D. Williamson, J. C. Scott et al. 2004. Evolutionary genetics: Ambiguous role of CCR5 in Y. pestis infection. Nature 430:417.

Fernandes, A. T., and A. Brehm. 2002. Population data of five STRs in three regions from Portugal. Forensic Sci. Int. 129:72-74.

Fernandes, A. T., R. Velosa, J. Jesus et al. 2003. Genetic differentiation of the Cabo Verde archipelago population analyzed by STR polymorphisms. Ann. Hum. Genet. 67:340-347. 
Galvani, A. P., and M. Slatkin. 2003. Evaluating plague and smallpox as historical selective pressures for the CCR5-A32 HIV-resistance allele. Proc. Natl. Acad. Sci. USA 100(25):15,276-15,279.

Ghilardi, G., M. L. Biondi, L. Battaglioli et al. 2004. Genetic risk factor characterizes abdominal aortic aneurysm from arterial occlusive disease in human beings: CCR5 432 deletion. J. Vasc. Surg. 40:995-1000.

Gonçalves, R., A. Rosa, A. Freitas et al. 2003. Y-chromosome lineages in Cabo Verde Islands witness the diverse geographic origin of its first male settlers. Hum. Genet. 113:467-472.

Grimaldi, R., N. Shindo, A. Xavier Acosta et al. 2002. Prevalence of the CCR5- 432 mutation in Brazilian populations and cell susceptibility to HIV-1 infection. Hum. Genet. 111:102-104.

Hopkins, D. 2002. The Great Killer: Smallpox in History. Chicago: University of Chicago Press.

Lalani, A. S., J. Masters, W. Zeng et al. 1999. Use of chemokine receptors by poxvirus. Science 286(5446):1968-1971

Libert, F., P. Cochaux, G. Beckman et al. 1998. The $\triangle$ CCR5 mutation conferring protection against HIV-1 in Caucasian population has a single and recent origin in northeastern Europe. Hum. Mol. Genet. 7(3):399-406.

Lucotte, G. 1997. Frequencies of the CC chemokine receptor $5 \Delta 32$ allele in various populations of defined racial background. Biomed. Pharmacother. 51:469-473.

Lucotte, G. 2001. Distribution of the CCR5 gene 32-base pair deletion in West Europe: A hypothesis about the possible dispersion of the mutation by the Vikings in historical times. Hum. Immunol. 62:933-936.

Martinson, J. J., N. H. Chapman, D. C. Rees et al. 1997. Global distribution of the CCR5 gene 32base pair deletion. Nat. Genet. 16:100-103.

Mecsas, J., G. Franklin, W. A. Kuziel et al. 2004. Evolutionary genetics: CCR5 mutation and plague protection. Nature 427:606.

Montiel, R., C. Bettencourt, C. Silva et al. 2005. Analysis of Y-chromosome variability and its comparison with mtDNA variability reveals different demographic histories between islands in the Azores archipelago (Portugal). Ann. Hum Genet. 69:1-10.

Pokorny, V., F. McQueen, S. Yeoman et al. 2005. Evidence for negative association of the chemokine receptor CCR5 $d 32$ polymorphism with rheumatoid arthritis. Ann. Rheum. Dis. 64:487-490.

Raymond, M., and F. Rousset. 1995. GENEPOP (version 1.2): Population genetics software for exact tests and ecumenicism. J. Hered. 86:248-249.

Russell-Wood, A. J. 1998. The Portuguese Empire, 1415-1808: A World on the Move. Baltimore: Johns Hopkins University Press.

Sabeti, P. C., E. Walsh, S. F. Schaffner et al. 2005. The case for selection at CCR5-432. PLOS Biology 3(11):1963-1969.

Samson, M., F. Libert, B. J. Doranz et al. 1996. Resistance to HIV-1 infection in Caucasian individuals bearing mutant alleles of the CCR5 chemokine receptor gene. Nature 382(6593):722-725.

Santos, C., M. Lima, R. Montiel et al. 2003. Genetic structure and origin of peopling in the Azores Islands (Portugal): The view from mtDNA. Ann. Hum. Genet. 67:433-456.

Schneider, S., J. M. Kueffer, D. Roessli et al. 1997. Arlequin (Version 1.1): A Software for Population Genetic Data Analysis. Geneva: Genetics and Biometry Laboratory, University of Geneva.

Spínola, H., A. Brehm, B. Bettencourt et al. 2005. HLA class I and II polymorphism in Azores show different settlements in Oriental and Central islands. Tissue Antigens 66:217-230.

Spínola, H., A. Brehm, F. Williams et al. 2002. Distribution of HLA alleles in Portugal and Cabo Verde: Relationships with the slave trade route. Ann. Hum. Genet. 66:285-296.

Stephens, J. C., D. E. Reich, D. B. Goldstein et al. 1998. Dating the origin of the CCR5- 32 AIDS resistance allele by the coalescence of haplotypes. Am. J. Hum. Genet. 62:1507-1515.

Trovoada, M. J., L. Pereira, L. Gusmão et al. 2004. Pattern of mtDNA variation in three populations from São Tomé e Príncipe. Ann. Hum. Genet. 68:40-54.

Wald, O., O. Pappo, Z. B. Ari et al. 2004. The CCR5 432 allele is associated with reduced liver inflammation in hepatitis C virus infection. Eur. J. Immunogenet. 31:249-252. 